\title{
Known Distribution of the Soybean Cyst Nematode, Heterodera glycines, in the United States and Canada in 2020
}

\author{
Gregory L. Tylka and Christopher C. Marett \\ Department of Plant Pathology and Microbiology, lowa State University, Ames, IA 50011
}

Accepted for publication 30 November 2020.

Keywords: soybean cyst nematode, SCN, Heterodera glycines, nematology, field crops, oilseeds, distribution, map

The soybean cyst nematode (SCN), Heterodera glycines Ichinohe, consistently is estimated to be the most damaging pathogen of soybean, Glycine max, throughout the areas of the United States and Canada that produce the crop (Allen et al. 2017; Koenning and Wrather 2010). Recent analyses using multiple statistical approaches estimated yield losses caused by SCN in the United States to total nearly $\$ 32$ billion from 1996 through 2016, which is more than $\$ 1.5$ billion annually (Bandara et al. 2020). The great magnitude of yield loss caused by SCN is due to its widespread distribution (Niblack et al. 2008; Workneh et al. 1999), its effective long-term survival in the absence of soybeans (Riggs 2004), and its ability to consistently reduce yields, particularly in hot, dry soils (McCarville et al. 2017).

Despite being widely distributed and causing significant yield reductions, SCN often goes unnoticed in fields because aboveground symptoms of damage and yield loss may not appear (Wang et al. 2003). Lack of detection is unfortunate, because left unmanaged, SCN population densities and the potential for yield loss steadily increase, and it is difficult to reduce population densities once they have reached highly damaging levels. However, growing resistant soybean cultivars in rotation with nonhost crops and using nematode-protectant seed treatments can prevent SCN population densities from burgeoning.

Maps illustrating the known distribution of SCN can be useful in raising awareness of the pathogen, in underscoring the importance of scouting fields for the presence of the pest, and in encouraging the sampling of fields to determine the population densities of the nematode. The most recent map of the known distribution of SCN in the United States and Canada was published in 2017 (Tylka and Marett 2017).

\section{Expanding Geographic Distribution}

University nematologists, plant pathologists, and plant disease clinic staff as well as state and provincial departments of agriculture personnel in the United States and Canada were contacted in 2020 and asked to identify counties and rural municipalities in which SCN was first found since 2017. The information obtained in 2020 was compared with the results of the survey that was published in 2017

${ }^{\dagger}$ Corresponding author: G. L. Tylka; gltylka@iastate.edu

*The $e$-Xtra logo stands for "electronic extra" and indicates that one supplementary gif is published online.

The author(s) declare no conflict of interest.

The authors retain the copyright for the map (Figure 1) and the animated series of maps (supplementary material). All other content is in the public domain and not copyrightable. It may be freely reprinted with customary crediting of the source. The American Phytopathological Society, 2021.
(Tylka and Marett 2017), and the map of the known distribution of SCN in the United States and Canada was updated. Information was not gathered from Illinois and Iowa in the United States because SCN has been found in all counties in those two states.

The survey conducted in 2020 revealed numerous counties and rural municipalities that were not known to be infested with SCN in 2017. The counties were located in 11 U.S. states and the provinces of Manitoba, Ontario, and Quebec. Specifically, there were 55 new U.S. counties (Table 1) and 24 new Canadian counties and rural municipalities (Table 2) identified as infested with SCN since 2017.

\section{TABLE 1}

Soybean cyst nematode-infested counties discovered in and reported from U.S. states since 2017

Counties

Kansas:

Ottawa, Marion

Kentucky:

Adair, Spencer

Michigan:

Gladwin

Minnesota:

Beltrami, Pennington, Marshall, Roseau

Nebraska:

Greeley

New York:

Albany, Allegany, Chautauqua, Chenango, Clinton, Columbia, Cortland, Delaware, Dutchess, Greene, Jefferson, Lewis, Livingston, Monroe, Montgomery, Niagara, Onondaga, Ontario, Orleans, Otsego, Rensselaer, Schuyler, Seneca, Steuben, St. Lawrence, Tompkins, Washington, Wayne, Wyoming

North Carolina:

Catawba, Montgomery

North Dakota:

Mercer, Ramsey, Towner, Ward, Wells

South Dakota:

Brule, Sanborn, Spink

Virginia:

Campbell, Culpeper, Lunenburg, Page

Wisconsin:

Kewaunee, Langlade 


\section{TABLE 2}

Soybean cyst nematode-infested counties and rural

municipalities discovered in and reported from Canadian

provinces since 2017

\section{Counties and rural municipalities}

Manitoba:

Emerson-Franklin, Montcalm, Norfolk-Treherne, Rhineland

Ontario:

Bruce, Hamilton, Simcoe, Waterloo, Wellington

Quebec:

Acton, Arthabaska, Bellechasse, Charlevoix, Drummond, Haut Saint-

François, Haut Saint-Laurent, Les Maskoutains, Les Sources, Lotbinière,

Mirabel, Pierre-de-Saurel, Pontiac, Québec, Val Saint-François

The 55 newly identified SCN-infested counties reported herein from 11 U.S. states during 2017 to 2020 were $50 \%$ more than in the previously published survey (Tylka and Marett 2017), representing 2014 through 2017, in which 37 new counties were identified. However, newly identified SCN-infested counties were found in only 11 states from 2017 to 2020 compared with in 17 states from 2014 to 2017. The state of New York had the greatest number of newly identified SCN-infested counties in the United States between 2017 and 2020, with 29. Quebec was the Canadian province with the greatest number of counties and rural municipalities in which SCN was found between 2017 and 2020, with 15 .

The map in Figure 1 shows the location of all of the counties and rural municipalities in which SCN was found between 2017 and 2020 as well as those previously known to be infested with the nematode. SCN has not yet been reported in the soybean-producing state of West Virginia in the United States or the soybean-producing Canadian province of Prince Edward Island.

\section{Considerations and Practical Implications}

There are several things to keep in mind about the survey results presented herein.

- Fields may be infested with SCN for many years before the infestations are discovered, because the distribution of SCN within fields usually is initially limited and can be aggregated

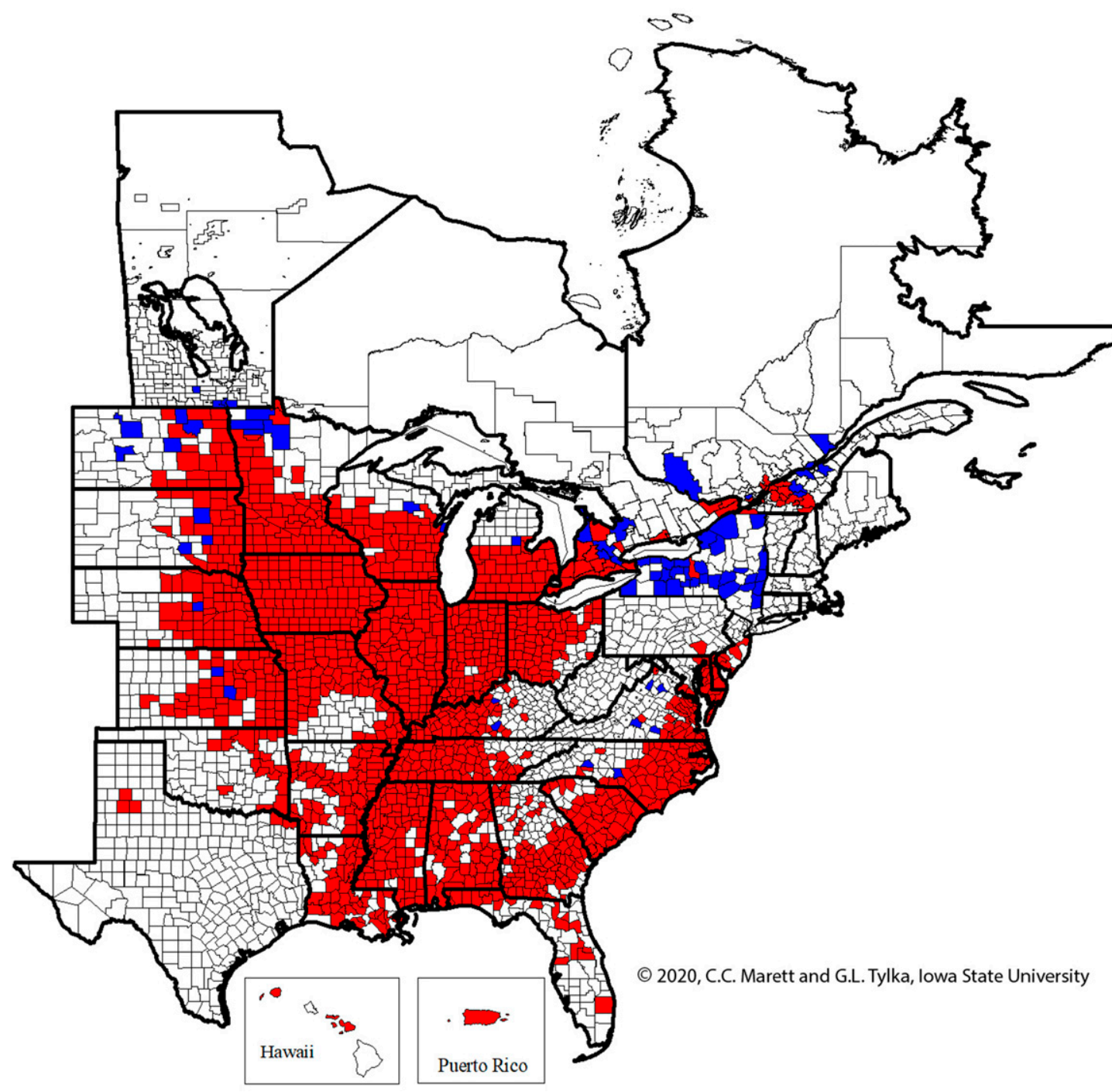

FIGURE 1

Known distribution of the soybean cyst nematode, Heterodera glycines, in counties and rural municipalities in the United States and Canada in 2020. Those reported as infested since 2017 are shown in blue; those known to be infested in 2017 or before are indicated in red. A corresponding animated gif appears in the supplementary material. Map ๑ C. C. Marett and G. L. Tylka, lowa State University, 2020. 
for many years. Also, the absence of symptoms contributes to infestations not being discovered soon after fields are initially infested. Consequently, one cannot assume that SCN initially moved into the counties and rural municipalities identified as newly infested in this survey in the past 3 years. Instead, the counties identified in this publication are newly discovered and reported to be infested with SCN since 2017.

- The number of counties in which SCN is first discovered can be greatly affected by the field survey activities of plant health professionals in the states and provinces during the timeframe covered by the survey. New SCN-infested counties more likely may be found in states and provinces where active surveys are being conducted than in states and provinces in which no such survey activity is occurring. For example, many of the 29 counties in which SCN was first discovered in New York since 2017 were identified during a survey coordinated by the New York State Integrated Pest Management program in collaboration with Cornell Cooperative Extension specialists (Jaime Cummings, personal communication).

- Soybeans have not been grown for several decades in some counties that were previously identified as having fields infested with SCN in the map in Figure 1, and, thus, SCN likely is no longer present in fields previously known to be infested. Examples of this would include the SCN-infested counties in the states of Florida and Texas. The map in Figure 1 represents the cumulative known distribution of SCN in the United States and Canada since the pathogen was initially discovered in North Carolina in 1954 (Winstead et al. 1955).

- A county is designated as infested with SCN after discovery of the nematode in a single field in the county. However, the distribution of SCN within a county can vary widely among infested counties and likely is affected by the number of years that soybeans have been grown and that the pathogen has been present and possibly other factors such as soil type and topography, cropping system, and so on. The nematode likely is present in more fields in the newly identified SCN-infested counties than just where the initial infestations were discovered. Also, it is likely that the nematode is present in counties that have not yet been identified and indicated on the map.

- The information and map presented in this publication may not contain every newly identified SCN-infested county and rural municipality in the United States and Canada. That is, additional SCN-infested counties and rural municipalities may have been discovered after the manuscript was submitted, reviewed, and accepted for publication in Plant Health Progress.

\section{Summary}

The results reported herein reveal steady expansion of the distribution of SCN throughout the United States and Canada, and the pathogen almost certainly will continue to spread among and within soybean-producing areas of the continent. Continued sampling and scouting for detection of new infestations are warranted as the first step toward successfully managing SCN.

\section{Acknowledgments}

Sincere thanks are expressed to the many individuals in the United States and Canada who are too numerous to name but who provided updated information about the known distribution of SCN in the areas in which they work. Without their local expertise and willingness to share information, the known distribution of SCN could not have been updated.

\section{Literature Cited}

Allen, T. W., Bradley, C. A., Sisson, A. J., Byamukama, E., Chilvers, M. I., Coker, C. M., Collins, A. A., Damicone, J. P., Dorrance, A. E., Dufault, N. S., Esker, P. E., Faske, T. R., Giesler, L. J., Grybauskas, A. P., Hershman, D. E., Hollier, C. A., Isakeit, T., Jardine, D. J., Kelley, H. M., Kemerait, R. C., Kleczewski, N. M., Koenning, S. R., Kurle, J. E., Malvick, D. K., Markell, S. G., Mehl, H. L., Mueller, D. S., Mueller, J. D., Mulrooney, R. P., Nelson, B. D., Newman, M. A., Osborne, L., Overstreet, C., Padgett, G. B., Phipps, P. M., Price, P. P., Sikora, E. J., Smith, D. L., Spurlock, T. N., Tande, C. A., Tenuta, A. U., Wise, K. A., and Wrather, J. A. 2017. Soybean yield loss estimates due to diseases in the United States and Ontario, Canada, from 2010 to 2014. Plant Health Prog. 18:19-27.

Bandara, A. Y., Weerasooriya, D. K., Bradley, C. A., Allen, T. W., and Esker, P. D. 2020. Dissecting the economic impact of soybean diseases in the United States over two decades. PLoS One 15:e0231141.

Koenning, S. R., and Wrather, J. A. 2010. Suppression of soybean yield potential in the continental United States by plant diseases from 2006 to 2009. Plant Health Prog. 11. doi: 10.1094/PHP-2010-1122-01-RS.

McCarville, M. T., Marett, C. C., Mullaney, M. P., Gebhart, G. D., and Tylka, G. L. 2017. Increase in soybean cyst nematode virulence and reproduction on resistant soybean varieties in Iowa from 2001 to 2015 and the effects on soybean yields. Plant Health Prog. 18:146-155.

Niblack, T. L., Colgrove, A. L., Colgrove, K., and Bond, J. P. 2008. Shift in virulence of soybean cyst nematode is associated with use of resistance from PI 88788. Plant Health Prog. 9. doi: 10.1094/PHP-2008-0118-01-RS.

Riggs, R. D. 2004. History and distribution. Pages 9-39 in: Biology and Management of Soybean Cyst Nematode, 2nd Ed. D. P. Schmitt, J. A. Wrather, and R. D. Riggs, eds. Schmitt \& Associates of Marceline, Marceline, MO.

Tylka, G. L., and Marett, C. C. 2017. Known distribution of the soybean cyst nematode, Heterodera glycines, in the United States and Canada, 1954 to 2017. Plant Health Prog. 18:167-168.

Wang, J., Niblack, T. L., Tremaine, J. N., Wiebold, W. J., Tylka, G. L., Marett, C. C., Noel, G. R., Myers, O., and Schmidt, M. E. 2003. The soybean cyst nematode reduces soybean yield without causing obvious symptoms. Plant Dis. 87:623-628.

Winstead, N. N., Skotland, C. B., and Sasser, J. N. 1955. Soybean cyst nematode in North Carolina. Plant Dis. Rep. 39:9-11.

Workneh, F., Tylka, G. L., Yang, X. B., Faghihi, J., and Ferris, J. M. 1999. Regional assessment of soybean brown stem rot, Phytophthora sojae, and Heterodera glycines using area-frame sampling: Prevalence and effects of tillage. Phytopathology 89:204-211. 